The Geneva Papers on Risk and Insurance, 22 (No. 82, January 1997) 413-425

\title{
The EU Proposal for a Council Directive on Export Credit Insurance: A Critical Evaluation
}

\author{
by David Camino and Clara Cardone*
}

\section{Introduction}

Export financial flows, whether direct or insured, are vital for the smooth functioning of the international trading system and all major exporting countries, including most European economies, have established national schemes to assist and protect exporters by providing financial and insurance facilities and reduce both the costs and risk involved in exporting. Assessing the effectiveness of these export promotion services is, however, a complex issue. Government reports have suggested uncertainty about support program effects on user firms and have highlighted the lack of clear evaluation criteria for such programs ${ }^{1}$. Even some doubts have arisen about the costs of such policies and the significance of the benefits obtained. Furthermore, some countries have viewed with growing concern the funding and public involvement in export finance as a new form of unfair competition in the international markets.

The EU Commission, concerned about the cost to national budgets of export credit insurance public policies (more than ECU 7 billion of losses for the EU country members in the last three years) ${ }^{2}$ has, after some hesitation, made up its mind concerning the harmonization of state-supported export credit insurance programs in the EU.

Designed to facilitate cooperation among the insurance agencies in the EU, the proposed Directive would establish common principles for medium- and long- term export credit insurance guarantees and premiums. In doing so, it gives national regulatory authorities and insurance credit agencies room of maneuver on official supported export insurance policies, as Member States are very reluctant to give up what they consider part of their foreign policy (Commission, 1994 p.2).

The aim of this paper will be then to assess the role of export insurance systems in the European Union at the light of the proposal for a Council Directive (1994) on harmonization of the export insurance main provisions. We will argue that the incentives induced by

* Universidad Carlos III de Madrid and Fundación MAPFRE Estudios Madrid.

1 See Seringhaus F.H. Rolf and Rosson, Philip (1990).

2 See Commission of the European Communities $(1994$, p.2) for the Proposal for a Council Directive on harmonization of the main provisions concerning export credit insurance for transaction with medium- and long-term cover. 
the proposed Directive are hardly compatible with the aim of the European Union to greatly reduce or eliminate competitive distortions on exports, given the existing rates of subsidization and the relationship framework between public and private insurers that still remains unsolved.

The paper is divided into five parts: After this introductory part, in sections two and three we will analyze the basic aspects of the European Insurance Single Market, as well as the main characteristics of Export Credit Insurance Programs in the EU.

In the next section of the paper, we will identify some of the key features of the proposal for the Directive on export credit insurance and how harmonization policies may reduce competitive distortions on premia and cover policies, although it may not eliminate them completely, as it sets only munimum standards for cover ${ }^{3}$.

In section four we will also highlight the relationship between private and public export credit insurers, as well as the need to avoid those aid elements that will be considered incompatible with the EU-Treaty. We will make a distinction between commercial and political risk, which means when insurance business is conducted on the insurer's own or on the Government's account. We will show that the distinction is a relevant one vis-à-vis the existing subsidy rate levels on export credit insurance.

Finally, section five contains some concluding comments and remarks.

\section{Export credit insurance}

Export Insurance is an integral part of the export support programs used by governments to promote national exports and can broadly be classified into three main categories:

- Commercial: such as information, market research, exhibition centers, trade fairs, etc.

- Fiscal: Including reduced tax rates for exporters, reimbursement of VAT, tariff exemptions, etc.

- Financial: export credit, credit insurance and official development assistance.

Export finance, considered in a broad sense, includes both credit and insurance, and is taken to mean the "set of facilities, usually provided by Government agencies, available to an exporter in any country which help to reduce the costs and risks involved in his export business" 4 and includes, therefore, a mixture of insurance and banking devices means as a way to increase exports. Credit and credit insurance have been accepted by the former GATT (now WTO) and the EU Commission as a legitimate form of export promotion, but not as a form of export subsidy5.

Member countries of the EU are subject, however, to legal constraints that are more comprehensive on export credit than those applied to insurance. This leaves room for export subsidization as international agreements only prohibit export financing which eventually entails a charge on the public account, on a long-term basis.

\footnotetext{
${ }^{3}$ This clearly reflects the principle of subsidiarity which characterizes the current philosophy of the European Union.

${ }^{4}$ See the Euromoney Guide to Export Finance (1986), p. 137.

5 The Commission of European Communities in a Document (1990), developed a framework and methodology to estimate subsidies on export finance, and calculated subsidy equivalents for Belgium, France, Germany and the United Kingdom.
} 
Export insurers are both in competition and communication with each other through different agreements, specially the "Consensus" on Export Credit and the "Berne Union" on Insurance. Although, the agencies in the Berne Union share, basically, the same economic objectives of export promotion and financial equilibrium, not two national export agencies are identical, as each operates in its own commercial and political environment (economic and political background, banking and insurance facilities, etc.).

The flexibility of the agencies (ECA's), in the European Union, varies largely with the degree of financial autonomy from their respective governments, although the export financial systems can be classified, according to the role played by the public sector, into two main groups:

- Countries (such as the United Kingdom or Germany) where public support is restricted to insurance and guarantees, leaving export credits to the banking system (Pure cover).

- Countries (such as Belgium, France or Spain) where public institutions have been set up to facilitate export credits, in addition to insuring agencies (Financial Support).

\begin{tabular}{|l|l|l|l|}
\hline & PURE COVER & $\begin{array}{l}\text { Insurance or guarantees } \\
\text { given to exports or lending } \\
\text { institutions }\end{array}$ \\
& $\begin{array}{l}\text { Export credit } \\
\text { agencies }\end{array}$ & Official \\
support & FINANCIAL SUPPORT & $\begin{array}{l}\text { Including direct credits, } \\
\text { refinancing and all forms of } \\
\text { interest subsidies }\end{array}$ \\
\hline
\end{tabular}

Source: OECD, 1990, pp.7-8

The problems faced by exporters and agencies are, nevertheless, similar, so it is not surprising that many systems have developed common types of insurance policies and guarantee facilities. The main risk covered is nonpayment, and can be either of a political or commercial nature.

- Political risk arises because of government imposed restrictions on foreign currency transactions or any event in the buyer's country that prevents it to meet its payment duties. Political events can cover a wide range of situations, from lack of foreign exchange to war conflicts.

- Commercial risk occurs because of the financial unwillingness or inability of the buyer to make payment, due to insolvency or bankruptcy.

Export insurance can be extended by the Supplier or Buyer, over different time lengths:

\begin{tabular}{|lll|}
\hline$*$ & $\begin{array}{l}\text { short term } \\
\text { medium term } \\
\text { long term }\end{array}$ & $\begin{array}{l}\text { (below 2 years) } \\
\text { (two to five years) } \\
\text { (over five years) }\end{array}$ \\
\hline$*$ & $\begin{array}{l}\text { "supplier creditors" } \\
\text { "buyers creditors" }\end{array}$ & $\begin{array}{l}\text { extended by the exporter } \\
\text { the exporters bank or other financial institution lend to the } \\
\text { buyer (or his bank) }\end{array}$ \\
\hline
\end{tabular}

Source: OECD, 1990, pp. $7 \cdot 8$ 
Concerned about the effects of government interference in markets at the taxpayer's expense, EU countries have already bounded themselves (OECD Consensus) to disciplines restricting official support with regard to credit terms and had recently started negotiations aimed at reducing the distortions of competition on premiums and cover policies caused by the existence of different export credit insurance systems.

\section{Export insurance and the single market}

Insurance is a very complex financial service, covering a large number of different types of risks and having the potential to impact on every area of our lives ${ }^{6}$. The setting up of the unified European insurance market and the approval of the proposed Directive (Com. (94) 297 final) on export credit insurance may therefore have a significant impact on the operations of European insurers, as official and private export agencies from all European Community Member States will be placed gradually on the same footing. The first factor to be noticed will be deregulation followed by the opening of the market.

- Deregulation: Deregulation is gaining ground strongly, under the combined pressure of exporters and EU regulators and also from the increasing temptation from both bankers and insurers, to play in each others' ground.

- Market opening: The unified insurance market, once full in force, will result in two main consequences: competition will be harder between the public European agencies already established in the market, and outsiders will be more attracted by the internal market.

The single European Insurance Market, that came into force on July 1994, and consisting currently of $15 \mathrm{Member}$ States, is in terms of customers the largest market in the world (325 million people or $25 \%$ of the worlds' wealth) where insurance companies can operate on the basis of a single licence. European Union Member States by this date are supposed to have implemented the European Directives into their national legislations, including the following main features ${ }^{7}$ :

- All European insurers will be free to establish a branch or an agency anywhere in the Community.

- All European insurers will be free to sell their policies in any European country, even without being established there.

- The insurers who want to make use of there "freedom" of establishment and to provide services abroad will not need any licence beyond the one they have already received from their home state supervisory authority.

- And even as far as he does business abroad, the insurer will be subject and responsible only to his home State supervisory authority.

The different situations of the agencies are reflected in their degree of financial autonomy: Sometimes they are required to be self-sufficient, at least in the medium term, while in other cases they are supported by the national budget and therefore face fewer immediate

\footnotetext{
6 See Boléat, M. J. (1995) review of the EU Insurance Directives in the "European Single Insurance Market", The Geneva Papers on Risk and Insurance, 20 No. 7.

7 The text is based on a lecture given by Dr. H. Schlude in his address to the "Joint Meeting" of the Credit and Insurance Committees of the ICIA, Biarritz 1993.
} 
financial constraints. The completion of the European Union and the introduction of the European Directive on export credit insurance will have a significant effect on their status. If the agencies are to compete for credit insurance business then "they must leave the protection of the public sector or face otherwise attacks from private insurers alleging unfair competition as a result of government support" (Smith, 1990).

In certain export contracts, particularly those in the capital goods' business, the level of support the exporter receives from his agency may be of crucial significance in the bidding process. Official support is likely to be of critical importance where the credit standing of the buyer is poor. It follows, therefore, that export competitiveness will be influenced by the national export credit insurance system.

The agreement (Council Directive), when in force, will prevent agencies from giving preferential treatment to their own nationals in providing support for intra-European trade; harmonization will be sought regarding common cover policies and premium rates and although opinions differ on whether agencies will be able to continue to provide "political risk" support for extra-European trade, substantial changes will take place in this field.

The implications of these changes are a matter of concern for exporters, insurers and government regulators and although in the case of short term insurance, the proposed Directive will not introduce substantial changes in the present situation, for medium- and long-term insurance contracts there is likely to be a much greater degree of discrimination between risks and premium rates that will reflect this fact.

A second important basic factor affecting the strategy of European insurers is the trend in the risks to be insured. In the mid 1990's many agencies belonging to European Union Country Members were still suffering strong financial pressures due to record claims payments that exceeded by far the sum of premium incomes and recoveries. The number of large and very large losses and the claim amounts payable, as a result, are continuously rising.

This is specially true of risks involving large companies operating in developing countries, as is the case of multinational companies, owing to their worldwide logistical structure: small individual losses may lead to large consequential losses. It is often difficult, however, to ascertain whether such losses are due to a cyclical behavior of the economy or to changes in "the cause-of-loss" systems.

Remarkably, an international uniform trend is to be seen in the large and very large losses experienced in the 1990's, mainly because of the increasing accumulations of exports in some countries, although there is every reason to believe that the causes of loss are changing dynamically, as exporters are taking insurance for granted even under difficult circumstances. These developments affecting risks raise a few questions as insurers are coming upon "limits to insurability" because the premiums obtainable and the available, security funds are not in the right proportion to each other.

Consequently, many export creditors and insurers, especially in the EU, have strengthened their country risk assessment procedures, leading to a sharp decline in the volume of exports officially financed and insured. This decline has been specially important for medium and long-term credit insurance for developing countries, where agencies feel that risks are to be taken in a case by case basis and be considered for specific policies on market 
terms: the level and kind of risks taken by the agencies (whether of commercial or political nature) will have a big impact on agencies' results once subsidies on negative net cash-flows are considered ${ }^{8}$.

In spite of difficulties, there have been relatively few changes in premium rates since the increase in the 1982-1984 period, and therefore total premium income has remained low due to the decline in business volume. The agencies do not consider premia as a major measure to limit exposure. Although some of them maintain a premium structure directly linked to country-risk, most agencies do not discriminate premium across countries.

The trend toward a more differentiated premium structure that began with the 1983 crisis has continued.

- In recent years, most agencies have come under domestic political presure to put their operations on a more commercial footing.

- Accounting treatments have become more transparent.

- The magnitudes of cash flows deficits have become more apparent to both parliamentary supervisors and the public in general.

Almost all agencies reported that in recent years they had raised premiums for cover for high-risk markets and lowered them for low-risk markets. At the same time, agencies have become increasingly flexible in the operation of their premium structures, adjusting them more quickly in response to current developments. This permitted them to offer cover at a price for export to countries facing difficulties external payments prospects, while at the same time allowing them to compete more effectively for business in good markets (Kuhn, Horvath and Jarvis, 1995).

As a consequence, there is some concern that premiums may sharply rise to ensure that they relate more closely to risks, rendering them somehow uncompetitive in world markets, specially when compared to other highly subsidized countries. This concern clearly reflects the need for a bigger "consensus" on export credit insurance policies, perhaps in the OECD forum of the "Berne Union".

To achieve this goal, it will be necessary to abolish the major existing barriers for access to each other's markets which originated from the different prudential supervisory regimes of the Member States. One of the main barriers was the fact that governments traditionally supervised insurance activities by a prior vetting and approval of the contract conditions and, in some cases, also of premiums and cover policies. However, "in order to facilitate business abroad it was necessary to replace this prior control with a non-systematic control ex-post. This in itself had necessarily important deregulatory effects" (Schlude, 1993).

\footnotetext{
${ }^{8}$ Messerlin P. (1986) and Melitz J. \& Messerlin P. (1987), provided estimates of subsidies in export credit and export insurance for Belgium, France and the United Kingdom. While for commercial risk the results of the agencies were almost break even, political risk accounted for a net negative cash flow.

A Negative cash-flow of agencies is accounted for by claims, with the remainder coming from interest and from administrative expenses. The Positive cash-flow includes recoveries and premia, that is the amounts paid by insured lenders as the price of the insurance.
} 


\section{The Council's directive proposal}

Credit insurance has been extensively used by governments to promote exports, which, in turn, means that virtually any proposal put forward by the European Commission on this field has possible implications for insurers and exporters, "who need to influence the debate and to remain on the alert to make sure that they are aware of new proposals and able to submit their views at an early stage so that the implications can be properly considered and any necessary changes made before the proposals become set in stone" (Boléat, 1995 p. 45).

Most of the changes will result in tougher competition, out of which only the best organizations will survive, but so far, few agencies have managed to cooperate and negotiate effectively a unified approach to the provision of export insurance. Despite the long term establishment of the Berne Union forum, only marginal advances have been reached on a common approach to export insurance. Although the agreement on export interest rates in the Consensus is working fairly well, little or no progress has been achieved on the harmonization of premium charges and cover capacity, primarily because of growing international competition.

In the Community it was apparent from the outset that the Member States' systems for granting aid for exports to third countries needed to be harmonized, and, indeed, this objective is explicitly set out in articles 112 and 113 of the Treaty establishing the European Union. The Council set up a Policy Coordination Group for Credit Insurance, Credit Guarantees and Financial Credits in 1960. Its purpose was to frame proposals for harmonizing Member States' credit insurance arrangements, and such terms were indeed enacted in a Council Directive adopted on 29 October 1970, which, however, remained dead letter. "None of the initiatives mooted since then, including the establishment of an European credit insurance system and, more recently, the creation of a credit insurance pool for Eastern Europe, has borne fruit" (Commission 1994, p. 2).

Although harmonization means getting closer but within certain margins, it is plain from the experience of the last thirty years that "Member States are exceedingly reluctant to give an inch of their freedom of maneuver on official supported export credits" (Commission 1994, p. 2), partly on political grounds, since they regard export policy to some extent as a foreign policy tool, and partly for financial reasons, since the cost of claims to the public purse is quite considerable (one credit insurance body, only, has paid out 20 billion SDRs in claims over the past eight years) ${ }^{9}$.

In each area, the overall aims of the directive is, therefore, to define a "best practice" approach to export credit insurance based on the European experience. The key points include ${ }^{10}$ :

- The general objective of setting premiums and regulating country coverage so that total premium income reflects risk and broadly covers the long-term costs arising from claims.

\footnotetext{
${ }^{9}$ See the explanatory memorandum of the Commission of the European Communities (1994) for the Proposal for a Council Directive on harmonization of the main provisions concerning export credit insurance.

10 See Kielmas (1994).
} 
- The principle that a proportion of loss is left with either the exporter, the export credit institution or both, so that they will have a consistent incentive to make responsible judgements on when to grant coverage.

- The progressive alignment of premium and country cover, so distortions of competition among member state exporters will be reduced.

The principle of subsidiarity, which leaves the implementation of the Directive in the hands of national authorities, although subject to minimum standards is a potentially consolidating device. By establishing certain minimum levels of coverage and then allowing countries to adopt higher standards, the proposed Directive provides for a learning period, which can set the stage for further harmonization.

Whether this principle of subsidiarity will be operational or not should largely depend on how the specific EU Directive may influence market behaviour. Even though existing differences in coverage by the national export insurance systems will prevail, there will be incentive for all regulatory systems to converge. But to what level?

To the extent that the regulatory authorities are fully independent of political pressure and the insurance industry itself, the expectation would then be that the goals of a more free competition and financial safety will be pursued. However, if such an independence does not prevail, there will always be the concern that the export insurance system in one or more countries will seek to achieve competitive advantage by influencing the extent and implementation of national regulation. The Council Directive on Export Credit Insurance "should not take into consideration the possibility of increased competition in laxity"11.

The application of the principle of subsidiarity arises in two main different ways in the proposed Directive, as:

(i) To set some common principles for the main constituents of cover.

The proposed Directive applies to the bulk of medium and long-term credit insurance, either for buyer or supplier credit contracts on public and private borrowers, including the kind of risk covered, cause of loss, percentage of cover and claim waiting period for manufacturing and credit risk. Although cover terms for public works and construction contracts, bonds and leasing contracts are not yet included, they also need to be harmonized in the near future.

The new system, induced by the proposed Directive may also result in cover rationing where insurers carry large exposures. The combined effects seem likely to result in increased costs and uncertainties for exporters. However, the desire to retain government political reinsurance is, perhaps, logical as governments are often best able to resolve the political difficulties associated with these risks.

(ii) To fix basic principles for setting premium rates.

A common model for setting premiums, based on a risk score (political or commercial risk), status of the buyer (public or private guarantor), securities as collateral (credit or manufacturing risk), duration (short- and long-term) and country risk assessment, needs to be accepted in order to assure that the premiums charged by credit insurers should correspond to the level of risk insured.

${ }^{11}$ See McKenzie and Khalidi (1994), critical evaluation on the problems of the Directive on the harmonization of Deposit Insurance in Europe. 
Premium incomes have two main elements: Basic insurance and the surcharge, which depends on risk, length of term and the amount of the contract. Surcharges that would fully. compensate, according to insurance principles, for high risk contracts and countries would be, however, too high and politically impracticable.

\subsection{Export insurance agencies and their governments}

One of the means to promote exports in the EU countries was the establishment of public or state backed export credit insurance agencies offering cover for so-called political and commercial risks. The relationship between the agencies and their governments are varied and often complex, although all agencies that rely on financial support from governments are ultimately accountable to those governments, and all have "guardian authorities" who direct overall policies regarding official support, and who represent them in intergovernmental fora (OECD, 1995).

This did not pose a major problem as long as the private credit insurers were not interested in this sort of business and competition among country members was not distorted. The situation, however, changed suddenly as all Member States' public export credit insurance systems were experiencing financial difficulties and consideration was being given to ways in which expenditure could be cut back.

The main concern for regulators, when the private insurers became interested in parts of this activity, that is, in short-term commercial, and sometimes, political risks, was the setting up of safety rules followed closely by competition. Private insurers claimed that public and private insurers were not subject to the same rules and that public insurers were benefitting from advantages which were not accessible to the private ones, in short that there was a distortion of competition in the export credit insurance market.

The existence of private insurance schemes in some Member States and public systems in others could also create competitive distortions. Some governments have argued that private schemes may be incapable of dealing with widespread insolvency arising from systematic factors operating throughout a given national or regional economy. As a consequence, insured companies may lose confidence in the guarantor, thereby decreasing the probability that these insurers take on political risk. In contrast, export companies will perceive that a public scheme will always receive lender of last resort facilities should its reserves be depleted.

The Commission has finally made up its mind concerning state-backed export credit insurers and is adopting guidelines as to what Member States are allowed or not allowed to do under the Articles 92 and 93 of the Treaty, dealing with State aids: In a so-called "Communication to the Member States", the Commission states that aid elements as those already pointed out, such as:

- the fact that public export credit insurance companies are not subject to the same prudential rules as are private export credit insurers or, more interestingly,

- the free use of an existing infrastructure at State level. In particular free access to privileged information via the use of Embassies to gather information about debtors,

and that those aid elements that will distort competition, and will be considered incompatible with the EU-Treaty. 
The Member States are requested in this communication to amend their export credit insurance systems for marketable risks for debtors established in any OECD country in conformity with the following guidelines (Schlude, 1993):

- State guarantees to insurers must be abolished.

- State reinsurance systems for marketable risks must be open to interest private insurers.

- Exemptions from taxes and similar charges granted to public export credit insurers, as far as they insure marketable risks, must be withdrawn.

- The provision of capital or other forms of finance to the marketable risk account business of public insurers can only take place if, under similar circumstances, this would be acceptable for a private investor acting under normal market conditions.

- Unless private export credit insurers can obtain free or under the same infrastructure at State level or under the same conditions as public insurers, such facilities may no longer be made available to public insurers in the future.

- Public and publicly supported export credit insurers should be subject to the same prudential rules as are private export credit insurers. Therefore, if public companies wish to operate in both the marketable and the non-marketable risk sectors, such operations should be maintained by keeping separate accounts for their business in these two fields.

Nevertheless, this is an area where the private insurance sector can contribute constructively to the discussion by putting forward possible solutions, although care will need to be taken that governments do simply try to pass the problems of poor risks and inadequate financing mechanisms in export credits to the private sector.

\subsection{Commercial vs. political risk}

The previous point has made quite clear that, although the main risk covered by export insurance is the one of non-payment, a distinction has to be made when the risk is of sovereign (a public or private buyer with a public guarantee) or corporate nature. The former, called political risk, is often covered on behalf of the exporter's government, but in the second case (commercial risk) the agencies usually act on their own account. If there exists a comprehensive export credit insurance scheme, the burden of the risk arising from unforeseen circumstances shifts away from the exporter or creditor to the guarantor (insurer). If the insurer is a private sector institution, it will set premiums in such a way as to reflect the probability that the guarantee will be exercised. This will depend upon the expected return and riskiness of the insurance contracts' portfolio as well as a degree of uncertainty.

As competition can only be distorted in as much as there is a market, the Commission had to define this market. It did so by creating the notion of "marketable risk" (Schlude, 1993), that is defined as follows: "Commercial risks with respect to private debtors when the latter are established in any OECD country". For these risks the maximum risk period is two years. "Commercial" risks may be defined as follows:

- arbitrary repudiation of a contract by a debtor, i.e. any arbitrary decision by a private debtor to interrupt or terminate the contract without legitimate reason;

- arbitrary refusal by the private debtor to accept the goods covered by the contract without legitimate reason:

- "de iure" or "de facto" insolvency of the private debtor or his guarantor;

- non-payment by the private debtor or by a guarantor of a debt resulting from the contract. 
Establishing this definition the Commission, following the procedure applied by the so-called Callut report ${ }^{12}$. has used one decisive criterion: is private reinsurance available or not for certain risks? It was observed that the response was generally yes for commercial private buyer risks. With regard to political risks it appeared that there was, indeed, some capacity but this was deemed inadequate for being regarded as a market activity.

This does not mean, however, that political risks will be excluded forever. The Commission is well aware of the fact that the capacity of the private reinsurance market is flexible and so it does not exclude that the definition of marketable risks will change over time. The Commission is prepared to review it regularly - the Communication says "at least once a year" - and Member States will be asked to inform the Commission of any changes in the market for these risks (Schlude, 1993).

Most institutions cover both risks and will provide the exporter or its bank with some kind of insurance policy anticipating these eventualities. In assessing the competitive distortions arising from export insurance subsidies, the distinction between state-related, highly subsidized, political risk and other risky (commercial) activities may be important.

\section{Summary and concluding remarks}

The European Single Insurance Market has finally arrived with the implementation of the Third Directive on 1 July 1994 which means that seen from Europe, the world of export credit insurance is likely to face dramatic changes in the near future.

Export insurance is an instrument extensively used by EU governments to promote exports. By providing cover for their exporters against the risk of default, whether on commercial or political grounds, they encourage them to do business in markets presenting an element of risk which enterprises are unwilling or unable to bear themselves. Cover for political risk is often provided at premium rates that clearly do not reflect the level of risks involved and is, therefore, highly subsidized.

A substantial change in many public agencies involved in export insurance took place since 1982, when debtors started experiencing serious payment difficulties. Over the last fifteen years or so, the cost to national budgets has been particularly high because of claims arising from political contingencies, including the debt crisis, the Gulf War, and the collapse of the former Soviet Union (Commission, 1994).

Debt rescheduling and the resulting heavy claims payments by the agencies have caused, since then, an unprecedented deterioration in their financial position, leading to huge technical losses (i.e., more than ECU 7 billion for the Community over the last three years). In order to improve their financial position, most agencies are trying to become more active on the debt recovery, whether through direct negotiations with private firms or countries or by means of debt rescheduling through the Paris Club or similar agreements.

How losses are recovered depends, as well, on the organizational form of the institutions providing insurance or finance in each country. Some national organizations act both on behalf of their governments and/or on their own account, depending on the kind of risk taken (whether of commercial or political nature).

12 Named after Philippe Callut from the Belgian export credit insurer Office National du Ducroire (OND) and principal of the expert's group that advised the Community on export insurance reforms. 
Each Member State, therefore, has its own credit insurance system, with different guarantee arrangements, premiums and cover policies and the result is that Community exporters are not competing for business on a level playing field.

Designed to facilitate cooperation among exporters in different European Union countries, the proposed directive would establish common principles for state-supported medium- and long-term export credit insurance guarantees and premiums, on three main elements:

- The guarantee conditions in insurance contracts, including the types of risk and the percentage of loss covered, as well as those other rules that constitute the quality of the guarantee.

- The premium will be calculated in a way that will better reflect the risk involved in exporting.

- The availability of coverage, for different countries, which varies according to the creditworthiness and economic and political stability of the country and the extent of cover.

Set out above are the details of the proposed Directive affecting export credit insurance. This Directive will represent a remarkable achievement and provide a firm basis for the single market to develop. However, this development will only take place gradually, as insurers become geared up to providing policies designed to meet the new requirements. The pace of the new legislation, when in force, will undoubtedly be slower, but there are still a number of important issues to be dealt with, some of which will influence the development of market capacity.

We have also highlighted what has been done so far, and what remains to be done in order to grant that both Community public and private insurers will be insurers and will be competing on a level playing field. The existence of private insurance schemes in some Member States and public systems in others could also create competitive distortions. Some authors have argued that private schemes may be incapable of dealing with widespread insolvency arising from systematic factors operating throughout the economy. As a consequence, insured companies may lose confidence in the guarantor, thereby decreasing the probability that these insurers take on political risk. In contrast, export companies will perceive that a public scheme will always receive lender of last resort (state backed) facilities, should its reserves be depleted.

This relationship framework among private and public export insurers still remains unsolved, creating competitive distortions between Member Countries, which are likely to be under discussion during the months and even years to come. As pointed out by Boléat (1995) "insurers will also need to monitor the operation of the single market in order to discuss practical difficulties and bring these to the attention of supervisors at the European Commission". 


\section{REFERENCES}

BOLÉAT, M.J., "The European Single Insurance Market", The Geneva Papers on Risk and Insurance, 20 No. 74, pp. 45-56, Geneva 1995.

CAMINO, D., "Export Promotion Policies in Spain and other EC Countries: Systems and Performance" in "Export Development and Promotion: The Role of Public Organizations", editors F.H. Rolf Seringhaus and Philip J. Rosson; Kluwer Academic Publishers, Boston, 1991.

COMMISSION OF THE EUROPEAN COMMUNITIES, "Proposal for a Council Directive on harmonization of the main provisions concerning export credit insurance for transactions with medium- and long-term cover", COM (94), 297, Brussels, 1994.

EUROMONEY PUBLICATIONS, "The Euromoney Guide to Export Finance”, London, 1989.

EUROMONEY PUBLICATIONS, "Trade Finance World Export Credit Guide”, London, 1994.

KIELMAS, M., "Export Credit Directive", Business Insurance, 1994.

KUHN, M.G., HORVATH, B. and JARVIS, C., "Officially Supported Export Credits - Recent Developments and Prospects", World Economic and Financial Surveys, International Monetary Fund, Washington D.C., 1995.

MCKENZIE, G. and MANZOOR, K., "The EU Directive on Deposit Insurance: A critical evaluation”, Journal of Common Market Studies, Vol. 32, No.2, 1994.

MELITZ, J. and MESSERLIN, P., "Export Credit Subsidies", Economic Policy, OECD, Paris, 1987.

OECD, Organization for Economic Cooperation and Development, "The Export Credit Financing Systems in OECD Member Countries”, OECD, Paris, 1995.

SCHLUDE, H., "Insurance in the Single Market", Address to the joint-meeting of the Credit and Guarantee Insurance Committees of the ICIA, Biarritz, 1993 (unpublished).

SERINGHAUS, F.H. Rolf and ROSSON, Philip J., "Government Export Promotion: A Global Perspective", Routledge, London, 1990.

SMITH, D., "Export Finance: Market needs and mechanisms", Financial Times Business Information, London, 1990. 